\title{
О ВЛИЯНИИ ТЕКТОНИЧЕСКИХ НАРУШЕНИЙ И ПООРЕБЕННЫХ ДОЛИН НА ГИДРОГЕОЛОГИЧЕСКИЕ УСЛОВИЯ ПАНДИВЕРЕСКОЙ ВОЗВЫШЕННОСТИ ЭСТОНСКОЙ ССР
}

P. JOGAR, V. OLLI. TEKTOONILISTE RIKKEVOONDITE JA MAETUD ORGUDE MOJUST HUDRO. GEOLOOGILISTELE TINGIMUSTELE

P. JOGAR, $V$. OLLI. THE EFFECT OF THE TECTONIC FAULT ZONES AND BURIED VALLEYS UPON HYDROGEOLOGICAL CONDITIONS

Подземные воды карбонатных пород ордовика и силура Северной Эстонии, мощностью от 100 до 300 м, приурочены в основном к определенным стратиграфическим горизонтам или пачкам пород. Водоносные горизонты разобщены мергелями, глинистыми и мергелистыми малопроннцаемыми разностями известняков и доломитов (Верте, 1965; Йыгар, 1973). Нормальная стратиграфия рассматриваемых подземных вод местами искажается тектоническими нарушениями и глубоко (до 70 м) врезанными древними долинами, заполненными четвертичными отложениями.

По данным государственного геологического картирования, плотность линий тектонических нарушений на Пандивереской возвышенности и прнлегающих к ней территорий в среднем составляет около 0,07 км на $1 \kappa м^{2}$. Местами (окрестности населенных пунктов Водья, Пээтри, Анна и г. Пайде) она достигает $0,3-0,6 \kappa м / \kappa \mu^{2}$.

По гидрогеологическому значению и наличию тектонических нарушений территорию Пандивереской возвышенности можно разделить на 3 района (см. рисунок).

В районе $A$ развиты: зоны тектонических нарушений - сбросы (амплитудой 5-15 м) северо-западного направления, расположенные в окрестностях Вийтна и по линии Аэгвийду-Янеда-Амбла, а также Раквере-Кулленга; погребенные долины и связанные с ними предполагаемые зоны тектонических нарушений, прослеживаемые вдоль современных долин рр. Лообу и Валгейыги и в окрестностях пос. Аэгвийду и Нелиярве.

В районе $Б$ развита серия невыдержанных зон тектонических нарушений (амплитудой до 20 м) преимущественно северо-восточного направления около населенных пунктов Роосна-Аллику, Ярва-Яани, Водья, Анна и г. Пайде.

В районе $B$ известны зоны Азериского и Ахтмеского тектонических нарушений, прослеживающиеся в центральной части Пандивереской возвышенности на протяжении соответственно 80 и 50 км и выходящие за ее 


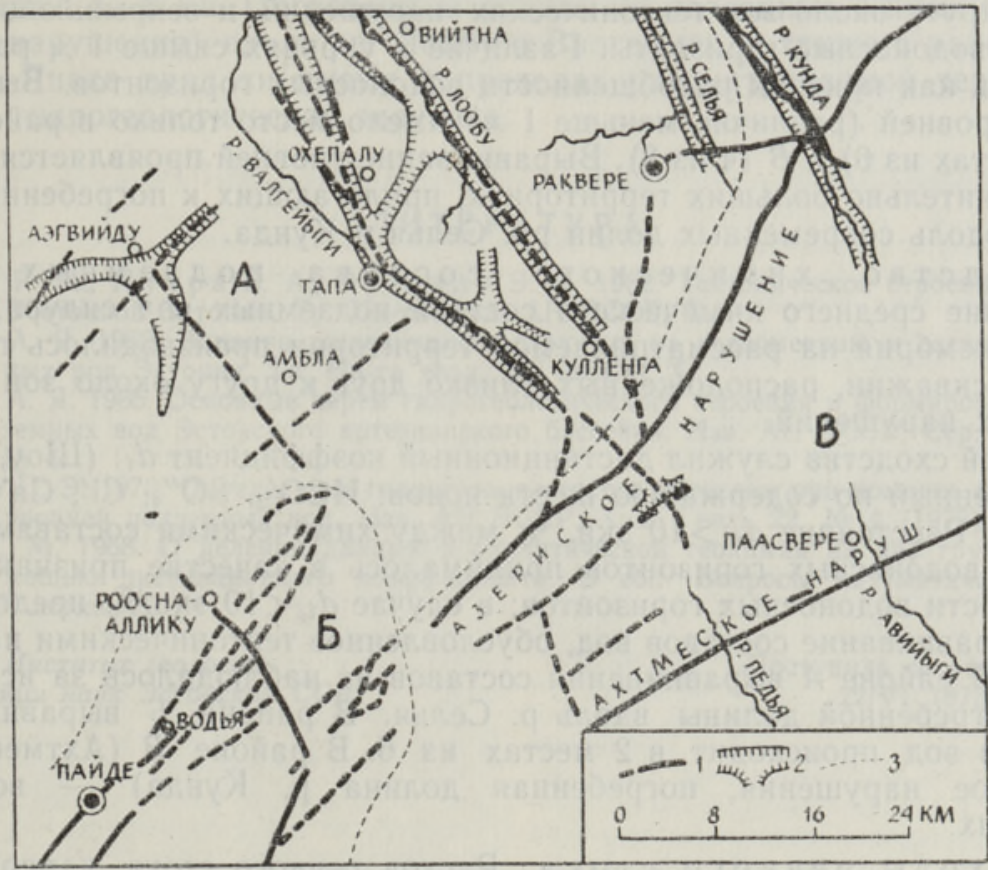

Районирование территорни исследований. (Тектонические нарушения и погребенные долины указаны по материалам Управления геологии CM ЭССР.)

1 - тектонические нарушения; 2 - погребенные долины; 3 - границы районов.

пределы. Ампілитуды вертикальных смещений слоев уменьшаются от 15-20 $\mu$ (около пос. Азери) до $3 \mu$ (юго-западная часть района). Установлено также несколько невыдержанных нарушений, расположенных в общем параллельно основным зонам. К этому району можно отнести и зону корытообразного тектонического прогиба и погребенную долину вдоль современной долины р. Кунда (Вахер и др., 1962).

А. И. Верте (1962) отмечает, что влияние тектонических нарушений и погребенных долин на гидрогеологические условия выражается прежде всего в выравнивании химического состава и пьезометрического уровня подземных вод поэтажно расположенных водоносных горизонтов.

Ниже приводятся некоторые данные о степени влияния зон нарушений и погребенных долин на распределение различных гидрогеологических параметров, характеризующих в некоторой мере вертикальную циркуляцию воды.

Распределение параметра водопрониц аемости. Коэффициенты фильтрации карбонатных пород ордовика и силура колеблются от 0,01 до 35 м/сут. Высокие значения коэффициентов фильграции (свыше $7 \mathrm{M} /$ сут) наблюдаются в скважинах, расположенных на расстоянии менее 1 км от тектонических зон, в 3,5 раза чаще, чем в скважинах на остальной территории (соответственно в 30 скважинах из 90 и в 35 скважинах из 360). Чаще всего высокие коэффициенты появляются в зоне Азериского нарушения (в 11 случаях из 25).

Распределение пьезометрических уровней напор . ны х вод. Выравнивание пьезометрических уровней определялось нами путем сравнения средних уровней в скважинах, расположенных близко 
друг к другу около зон тектонических нарушений и вскрывающих различные водоносные горизонты. Различие в уровнях свыше 1 м рассматривалось как признак разобщенности водоносных горизонтов. Выравнивание уровней (различие меньше 1 ) имело место только в районах $E$ (в 4 местах из 6) и $B$ (4 из 8). Выравнивание уровней проявляется также на сравнительно больших территориях, прилегающих к погребенным долинам вдоль современных долин рр. Селья и Кунда.

Сходство химического состава подземных вод. Сравнение среднего химического состава подземных вод силура, ордовнка и кембрия на рассматриваемой территории производилось по пробам из скважин, расположенных близко друг к другу около зон тектонических нарушений.

Мерой сходства служил дистанционный коэффициент $d_{i ;}$ (Шоу, 1968), определенный по содержанию шести ионов: $\mathrm{HCO}_{3}^{\prime}, \mathrm{SO}^{\prime \prime}{ }_{4}, \mathrm{Cl}^{\prime}, \mathrm{Ca}^{*}, \mathrm{Mg}^{*}$, $\mathrm{Na}+\mathrm{K}$. Расстояние $d_{i j}>10$ экв. \% между химическими составами различных водоносных горизонтов принималось в качестве признака разобщенности водоносных горизонтов; в случае $d_{i j}<10$ экв. \% предполагалось выравнивание составов вод, обусловленное тектоническими нарушениями. В районе $A$ выравнивания составов не наблюдалось за исключением погребенной долины вдоль р. Селья. В районе 5 выравнивание составов вод происходит в 2 местах из 6. В районе $B$ (Ахтмеское и Азериское нарушения, погребенная долина р. Кунда) - во всех 8 случаях.

Расходы речного стока. Расход речного стока измерялся в 98 гидростворах, расположенных в местах, где зоны тектонических нару亡ений пересекают русла современных поверхностных водотоков. В районе $A$ значительное увеличение подземного питания рек (более чем в 3 раза больше фонового - 1,5-3 $\left.л / с е \kappa \cdot \kappa \mu^{2}\right)$ наблюдалось в 5 , а поглощение - в 1 створе из 30 . В районе 5 увеличение подземного стока наблюдалось в 9 , а поглощение - в 1 створе из 25. В районе $B$ увеличение подземного стока отмечено в 13, а поглощение - в 8 створах из 43. Значительное увеличение подземного стока имеет место в районе южного склона Пандивереской возвышенности, а значительное поглощение - на погребенной долине р. Кунда.

Поверхность безнапорных вод. Уровни вод самого близкого к поверхности земли водоносного горизонта измерены во время летнего минимума в мелких колодцах, преимущественно в центральной части Пандивереской возвышенности. Установлено, что колодцы, расположенные в непосредственной близости от Азериской зоны нарушений, нмели более низкие уровни (на $2-7$ м) по сравнению с удаленными от нее колодцами (в районе пос. Варангу, Коэру и Пээтри). Такое же влия-

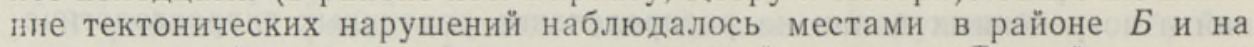
юго-восточной оконечности зоны нарушений вдоль р. Валгейыги, юговосточнее пос. Вяйке-Маарья.

В ы воды. Влияние тектонических нарушений и погребенных долин на водообмен подземных вод между водоносными горизонтами следует учитывать при проектировании водозаборов. В зонах тектонических нарушений вероятнее всего получить более высокие дебиты, но в то же время эти зоны ухудшают защитные свойства водоупоров против загрязнения. В районе Пандивереской возвышенности вертикальному водообмену и одновременно загрязнению особенно способствуют мощные зоны Азериского и Ахтмеского тектонических нарушений. Их влияние заметно даже на расстоянии $4-6 \kappa$.

Особо следует отметить влияние на водообмен погребенных долин вдоль рр. Кунда и Селья, которое также может распространяться на 
расстояния 4-6 км. Погребенные долины (и связанные с ними тектонические нарушения) вдоль рр. Лообу и Валгейыги, а также в районе Аэгвийду-Янеда вряд ли имеют в пределах рассматриваемой территории особое гидрогеологическое значение.

\section{Л И Т Е Р А Т У P A}

В ах ер Р. М., Пу ур а В. А., Эрисалу Э. К. 1962. Тектоническое строение СевероВосточной Эстонии. Тр. Ин-та геол. АН ЭССР, Х.

В ерте А. Я. 1962. Влияние тектонических структур на пьезометрию и состав подземных вод Эстонии. Тр. Ин-та геол. АН ЭССР, Х.

В е р те А. Я. 1965. Основные черты гидрогеологического строения и формирования подземных вод Эстонского артезианского бассейна. Изв. АН ЭССР, Сер. биол., 14 № 4.

Й ы а р П. Э. 1973. Определение гидрогеологического строения при помощи суммарных уровней подземных вод. Изв. АН ЭССР, Хим. Геол., 22, № 4 (1973).

Шоу Д. М. 1968. О делении данных в аналитической геохимии на две группы с помощью дистанционного коэффициента. В сб.: Вопросы математической геологии, Л.

Институт геологии

Академии наук Эстонской ССР
Поступила в редакцию $22 / \mathrm{VI} 1973$ 